\title{
Briarenols W-Z: Chlorine-Containing Polyoxygenated Briaranes from Octocoral Briareum stechei (Kükenthal, 1908)
}

\author{
You-Ying Chen ${ }^{1,2}$, Yi-Lin Zhang ${ }^{2,3}$, Gene-Hsiang Lee ${ }^{4}$, Lun Kelvin Tsou ${ }^{5}$, Mingzi M. Zhang ${ }^{6}$, \\ Hsing-Pang Hsieh 5,7,8, Jih-Jung Chen 9 (D), Chou-Yuan Ko 10,11, Zhi-Hong Wen 1,12,*(D) \\ and Ping-Jyun Sung 1,2,3,13,14,*(D)
}

Citation: Chen, Y.-Y.; Zhang, Y.-L.; Lee, G.-H.; Tsou, L.K.; Zhang, M.M.; Hsieh, H.-P.; Chen, J.-J.; Ko, C.-Y.; Wen, Z.-H.; Sung, P.-J. Briarenols W-Z: Chlorine-Containing Polyoxygenated Briaranes from Octocoral Briareum stechei (Kükenthal, 1908). Mar. Drugs 2021, 19, 77. https://doi.org/10.3390/md19020077

Academic Editor: Vassilios Roussis

Received: 2 January 2021

Accepted: 28 January 2021

Published: 31 January 2021

Publisher's Note: MDPI stays neutral with regard to jurisdictional claims in published maps and institutional affiliations.

Copyright: (c) 2021 by the authors. Licensee MDPI, Basel, Switzerland. This article is an open access article distributed under the terms and conditions of the Creative Commons Attribution (CC BY) license (https:// creativecommons.org/licenses/by/ $4.0 /)$.
1 Department of Marine Biotechnology and Resources, National Sun Yat-sen University, Kaohsiung 804201, Taiwan; D065020004@student.nsysu.edu.tw

2 National Museum of Marine Biology and Aquarium, Pingtung 944401, Taiwan; 610863012@gms.ndhu.edu.tw

3 Graduate Institute of Marine Biology, National Dong Hwa University, Pingtung 944401, Taiwan

4 Instrumentation Center, National Taiwan University, Taipei 106319, Taiwan; ghlee@ntu.edu.tw

5 Institute of Biotechnology and Pharmaceutical Research, National Health Research Institutes, Miaoli 350401, Taiwan; kelvintsou@nhri.edu.tw (L.K.T.); hphsieh@nhri.edu.tw (H.-P.H.)

6 Institute of Molecular and Genomic Medicine, National Health Research Institutes, Miaoli 350401, Taiwan; zhangmz@nhri.edu.tw

7 Department of Chemistry, National Tsing Hua University, Hsinchu 300044, Taiwan

8 Biomedical Translation Research Center, Academia Sinica, Taipei 115202, Taiwan

9 Faculty of Pharmacy, School of Pharmaceutical Sciences, National Yang Ming Chiao Tung University, Taipei 112304, Taiwan; jjungchen@nycu.edu.tw

10 Division of Gastroenterology, Department of Internal Medicine, Kaohsiung Armed Forces General Hospital, Kaohsiung 802301, Taiwan; gastroenterokjy@gmail.com

11 Institute of Medical Science and Technology, National Sun Yat-sen University, Kaohsiung 804201, Taiwan

12 Institute of BioPharmaceutical Sciences, National Sun Yat-sen University, Kaohsiung 804201, Taiwan

13 Chinese Medicine Research and Development Center, China Medical University Hospital, Taichung 404394, Taiwan

14 Graduate Institute of Natural Products, Kaohsiung Medical University, Kaohsiung 807378, Taiwan

* Correspondence: wzh@mail.nsysu.edu.tw (Z.-H.W.); pjsung@nmmba.gov.tw (P.-J.S.); Tel.: +886-7-525-2000 (ext. 5038) (Z.-H.W.); +886-8-882-5037 (P.-J.S.); Fax: +886-7-525-2021 (Z.-H.W.); +886-8-882-5087 (P.-J.S.)

Abstract: Briareum stechei is proven to be a rich source of 3,8-cyclized cembranoids (briarane) with a bicyclo[8.4.0] carbon core. In the present study, four previously unreported briaranes, briarenols W-Z (1-4), along with solenolide A (5), briarenolide M (6), briaexcavatolide F (7), and brianolide (8), were isolated and characterized through spectroscopic analysis, and the absolute configuration of $\mathbf{8}$ was corroborated by a single-crystal x-ray diffraction analysis. Briaranes $\mathbf{2}$ and $\mathbf{5}$ were found to induce significant inflammatory activity in lipopolysaccharide (LPS)-induced RAW 264.7 mouse macrophage cells by enhancing the expression of the inducible nitric oxide synthase (iNOS) and cyclooxygenase-2 (COX-2) proteins.

Keywords: Briareum stechei; briarane; briarenol; inflammation; iNOS; COX-2

\section{Introduction}

Since briarein A, a 3,8-cyclized cembranoid (briarane), was first reported from a Caribbean octocoral Briareum asbestinum (Pallas, 1766) in 1977 [1], hundreds of marine origin briarane diterpenoids with novel structures and extensive bioactivities have been obtained from various octocorals [2,3], of which octocorals belonging to the genus Briareum have been recognized as the most important source of briarane-type natural products [3]. In our previous studies, a series of interesting briarane-type diterpenoids, including briarenols A$\mathrm{T}$ [4-12], were isolated from various octocorals belonging to the genera Briareum, Junceella, and Ellisella, collected off the waters of Taiwan, and an anti-inflammatory assay was employed to evaluate the activities of these compounds in reducing the release of inducible 
oxide synthase (iNOS) and cyclooxygenase-2 (COX-2) in an in vitro pro-inflammatory macrophage culture model.

While most octocorals are classified as endangered species due to the exacerbating destruction of reef habitats, studies on the chemical constituents from cultured, potentially pharmaceutical, marine organisms have gained great attention [13]. Therefore, cultured octocoral Briareum stechei (Kükenthal, 1908) [14], originally dwelling in the waters of Taiwan, was selected for chemical investigation in our study. The results identified eight chlorinecontaining briaranes, including four new compounds, briarenols W-Z (1-4), together with known briaranes, solenolide A (5) [15], briarenolide M (6) [16], briaexcavatolide F (7) [17], and brianolide (8) [18] (Figure 1). This study carried out the isolation and identification of the isolates as well as analyzing their bioactivity.

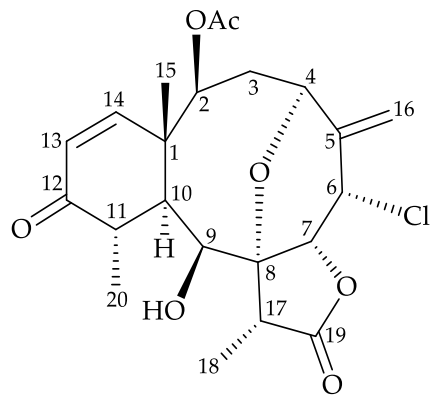

1

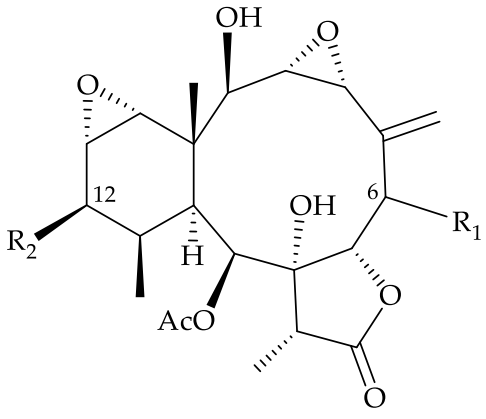

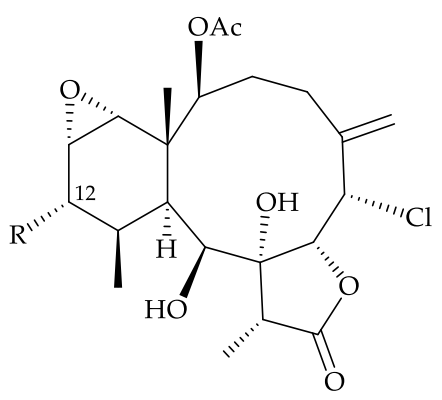

2: $\mathrm{R}=\mathrm{OC}(\mathrm{O})\left(\mathrm{CH}_{2}\right)_{2} \mathrm{CH}_{3}$

5: $\mathrm{R}=\mathrm{OC}(\mathrm{O})\left(\mathrm{CH}_{2}\right)_{4} \mathrm{CH}_{3}$

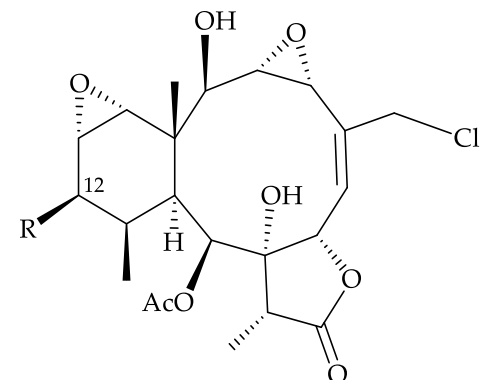

3: $\mathrm{R}=\mathrm{OC}(\mathrm{O})\left(\mathrm{CH}_{2}\right)_{2} \mathrm{CH}_{3}$ 6: $\mathrm{R}=\mathrm{OAc}$

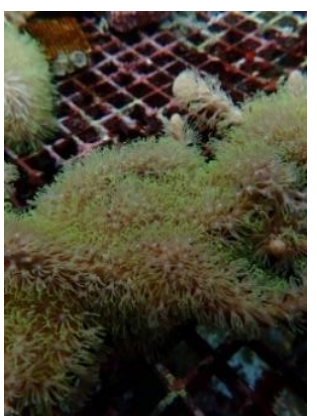

B. stechei

Figure 1. Structures of briarenols W-Z (1-4), solenolide A (5), briarenolide M (6), briaexcavatolide F (7), brianolide (8), and a picture of cultured B. stechei.

2. Results and Discussion

\subsection{Chemical Identification of Isolated Briaranes}

Freshly collected B. stechei were frozen and subsequently freeze-dried, powdered, and extracted with a mixture of methanol $(\mathrm{MeOH})$ and dichloromethane (DCM) (1:1). Silica gel chromatography of the extract, followed by high performance liquid chromatography (HPLC), yielded briaranes 1-8.

Briarenol W (1) was obtained as an amorphous powder. The positive mode electrospray ionization mass spectrum ((+)-ESIMS) showed a pair of peaks at $\mathrm{m} / \mathrm{z} 461 / 463$ $\left([\mathrm{M}+\mathrm{Na}]^{+} /[\mathrm{M}+2+\mathrm{Na}]^{+}\right)(3: 1)$, with a relative intensity suggestive of a chlorine atom. NMR data coupled with the $[\mathrm{M}+\mathrm{Na}]^{+}$peak in the (+)high-resolution ESIMS ((+)-HRESIMS) at $m / z 461.13377$ suggested a molecular formula $\mathrm{C}_{22} \mathrm{H}_{27} \mathrm{ClO}_{7}$ (calculated for $\mathrm{C}_{22} \mathrm{H}_{27}{ }^{35} \mathrm{ClO}_{7}$ $+\mathrm{Na}, 461.13375)$ that indicated nine degrees of unsaturation. The IR spectrum indicated the presence of hydroxy $\left(\nu_{\max } 3430 \mathrm{~cm}^{-1}\right), \gamma$-lactone $\left(\nu_{\max } 1780 \mathrm{~cm}^{-1}\right)$, ester carbonyl $\left(\nu_{\max } 1733 \mathrm{~cm}^{-1}\right)$, and $\alpha, \beta$-unsaturated ketonic $\left(\nu_{\max } 1670 \mathrm{~cm}^{-1}\right)$ groups. The ${ }^{13} \mathrm{C}$ NMR spectrum of 1 (Table 1) showed signals of 22 carbons. The multiplicity of the carbon signals was determined from the distortionless enhancement by polarization transfer 
(DEPT) and heteronuclear single quantum coherence (HSQC) spectra: four methyls, two methylenes (one olefin), ten methines (five bearing a heteroatom and two olefins), and six non-protonated carbons (three carbonyls, one olefin, and one bearing a heteroatom). From the ${ }^{13} \mathrm{C}$ and ${ }^{1} \mathrm{H}$ NMR spectra (Tables 1 and 2$), 1$ was found to possess a $\gamma$-lactone $\left(\delta_{\mathrm{C}} 175.3\right.$, C-19), an acetoxy $\left(\delta_{\mathrm{H}} 2.15,3 \mathrm{H}, \mathrm{s} ; \delta_{\mathrm{C}} 21.1\right.$, acetate methyl; $\delta_{\mathrm{C}} 170.6$, acetate carbonyl), an $\alpha, \beta$-unsaturated ketonic $\left(\delta_{\mathrm{H}} 6.95,1 \mathrm{H}, \mathrm{d}, J=10.8 \mathrm{~Hz}, \mathrm{H}-14 ; 5.95,1 \mathrm{H}, \mathrm{d}, J=10.8 \mathrm{~Hz}, \mathrm{H}-13 ; \delta_{\mathrm{C}}\right.$ 205.6, ketonic carbonyl, C-12; 156.3, CH-14; 126.0, CH-13), and an exocyclic carbon-carbon double bond $\left(\delta_{\mathrm{H}} 5.34,1 \mathrm{H}, \mathrm{d}, J=1.8 \mathrm{~Hz} ; 5.48,1 \mathrm{H}, \mathrm{d}, J=1.8 \mathrm{~Hz}, \mathrm{H}_{2}-16 ; \delta_{\mathrm{C}} 137.5, \mathrm{C}-5\right.$; $\left.116.1, \mathrm{CH}_{2}-16\right)$ moieties. Five double bonds accounted for five unsaturated degrees. The remaining four degrees of unsaturation defined $\mathbf{1}$ as a tetracyclic molecule.

Table $1 .{ }^{13} \mathrm{C}$ NMR data for briaranes 1-4.

\begin{tabular}{|c|c|c|c|c|}
\hline Position & $1^{a}$ & $2^{a}$ & $3^{b}$ & $4^{b}$ \\
\hline 1 & $44.2, \mathrm{C}^{\mathrm{c}}$ & $40.4, \mathrm{C}$ & $39.1, \mathrm{C}$ & $38.4, \mathrm{C}$ \\
\hline 2 & $76.3, \mathrm{CH}$ & $82.0, \mathrm{CH}$ & $76.2, \mathrm{CH}$ & $74.1, \mathrm{CH}$ \\
\hline 3 & $35.4, \mathrm{CH}_{2}$ & $25.3, \mathrm{CH}_{2}$ & $60.5, \mathrm{CH}$ & $62.4, \mathrm{CH}$ \\
\hline 4 & $76.6, \mathrm{CH}$ & $21.2, \mathrm{CH}_{2}$ & $58.1, \mathrm{CH}$ & $56.1, \mathrm{CH}$ \\
\hline 5 & $137.5, \mathrm{C}$ & $140.3, \mathrm{C}$ & $137.9, \mathrm{C}$ & $137.4, \mathrm{C}$ \\
\hline 6 & $54.9, \mathrm{CH}$ & $64.9, \mathrm{CH}$ & 126.1, $\mathrm{CH}$ & $63.2, \mathrm{CH}$ \\
\hline 7 & $80.4, \mathrm{CH}$ & $76.3, \mathrm{CH}$ & $76.7, \mathrm{CH}$ & 83.0, CH \\
\hline 8 & $82.4, \mathrm{C}$ & $86.1, \mathrm{C}$ & $81.7, \mathrm{C}$ & $80.9, \mathrm{C}$ \\
\hline 9 & $76.9, \mathrm{CH}$ & $71.8, \mathrm{CH}$ & $69.1, \mathrm{CH}$ & $69.5, \mathrm{CH}$ \\
\hline 10 & $45.8, \mathrm{CH}$ & $33.9, \mathrm{CH}$ & $36.5, \mathrm{CH}$ & $35.9, \mathrm{CH}$ \\
\hline 11 & $42.1, \mathrm{CH}$ & $36.8, \mathrm{CH}$ & $36.5, \mathrm{CH}$ & $36.0, \mathrm{CH}$ \\
\hline 12 & $205.6, C$ & $70.3, \mathrm{CH}$ & $71.6, \mathrm{CH}$ & $72.2, \mathrm{CH}$ \\
\hline 13 & $126.0, \mathrm{CH}$ & 49.7, CH & $57.2, \mathrm{CH}$ & $57.2, \mathrm{CH}$ \\
\hline 14 & 156.3, CH & $62.1, \mathrm{CH}$ & $62.1, \mathrm{CH}$ & $62.0, \mathrm{CH}$ \\
\hline 15 & $16.2, \mathrm{CH}_{3}$ & $20.2, \mathrm{CH}_{3}$ & $15.2, \mathrm{CH}_{3}$ & $15.3, \mathrm{CH}_{3}$ \\
\hline 16 & $116.1, \mathrm{CH}_{2}$ & $118.6, \mathrm{CH}_{2}$ & $44.1, \mathrm{CH}_{2}$ & $121.2 \mathrm{CH}_{2}$ \\
\hline 17 & $50.2, \mathrm{CH}$ & $44.4, \mathrm{CH}$ & $43.6, \mathrm{CH}$ & $46.1, \mathrm{CH}^{2}$ \\
\hline 18 & $8.2, \mathrm{CH}_{3}$ & $7.2, \mathrm{CH}_{3}$ & $6.3, \mathrm{CH}_{3}$ & $6.0, \mathrm{CH}_{3}$ \\
\hline 19 & $175.3, \mathrm{C}$ & $176.4, \mathrm{C}$ & $175.5, \mathrm{C}$ & $173.8, \mathrm{C}$ \\
\hline 20 & $15.4, \mathrm{CH}_{3}$ & $14.5, \mathrm{CH}_{3}$ & $9.7, \mathrm{CH}_{3}$ & $9.4, \mathrm{CH}_{3}$ \\
\hline \multirow[t]{2}{*}{ OAc-2 } & $170.6, \mathrm{C}$ & $168.3, \mathrm{C}$ & & \\
\hline & $21.1, \mathrm{CH}_{3}$ & $20.9, \mathrm{CH}_{3}$ & & \\
\hline \multirow[t]{2}{*}{ OAc-9 } & & & $169.5, \mathrm{C}$ & $169.9, \mathrm{C}$ \\
\hline & & & $21.8, \mathrm{CH}_{3}$ & $21.8, \mathrm{CH}_{3}$ \\
\hline \multirow[t]{4}{*}{ n-butyrate-12 } & & $173.3, \mathrm{C}$ & 173.1, C & 173.1, C \\
\hline & & $35.8, \mathrm{CH}_{2}$ & $36.2, \mathrm{CH}_{2}$ & $36.2, \mathrm{CH}_{2}$ \\
\hline & & $18.4, \mathrm{CH}_{2}$ & $18.4, \mathrm{CH}_{2}$ & $18.4, \mathrm{CH}_{2}$ \\
\hline & & $13.7, \mathrm{CH}_{3}$ & $13.6, \mathrm{CH}_{3}$ & $13.6, \mathrm{CH}_{3}$ \\
\hline
\end{tabular}

$\overline{\mathrm{a}} 150 \mathrm{MHz}, \mathrm{CDCl}_{3},{ }^{\mathrm{b}} 100 \mathrm{MHz}, \mathrm{CDCl}_{3},{ }^{\mathrm{c}}$ Multiplicity deduced by ${ }^{13} \mathrm{C}$, distortionless enhancement by polarization transfer (DEPT), and heteronuclear single quantum coherence (HSQC) spectra.

The H-2/H $\mathrm{H}_{2}-3 / \mathrm{H}-4, \mathrm{H}-6 / \mathrm{H}-7, \mathrm{H}-10 / \mathrm{H}-11, \mathrm{H}-13 / \mathrm{H}-14, \mathrm{H}-11 / \mathrm{H}_{3}-20, \mathrm{H}-17 / \mathrm{H}_{3}-18$, and $\mathrm{H}-6 / \mathrm{H}_{2}-16$ (by allylic coupling) spin systems, measured in the ${ }^{1} \mathrm{H}-{ }^{1} \mathrm{H}$ correlation spectroscopy (COSY) (Figure 2), were fit to the regiochemistry of vicinal couplings in 1 . The fused tetracyclic network was established by heteronuclear multiple bond coherence (HMBC) experiments, particularly by the ${ }^{2} \mathrm{~J}$ - and ${ }^{3} \mathrm{~J}-{ }^{1} \mathrm{H}-{ }^{13} \mathrm{C}$ long-range correlations between protons and non-protonated carbons such as H-9, H-10, H-13, H-14, $\mathrm{H}_{3}-15 / \mathrm{C}-1$; H-7, H16b/C-5; H-4, $\mathrm{H}_{3}-18$, OH-9/C-8; H-11, H-14, $\mathrm{H}_{3}-20 / \mathrm{C}-12$; and H-17, $\mathrm{H}_{3}-18 / \mathrm{C}-19$, thus permitted elucidation of the main carbon skeleton of 1 (Figure 2). The Me-20, Me-18, and Me-15 at C-11, C-17, and C- 1 were confirmed by the $\mathrm{HMBC}$ correlations between $\mathrm{H}_{3}$ 20/C-10, C-11, C-12; $\mathrm{H}_{3}-18 / \mathrm{C}-8, \mathrm{C}-17, \mathrm{C}-19$; and $\mathrm{H}_{3}-15 / \mathrm{C}-1, \mathrm{C}-2$, C-10, C-14, respectively. An exocyclic double bond at $\mathrm{C}-5$ was confirmed by the $\mathrm{HMBC}$ correlations between $\mathrm{H}_{2-}$ $16 / \mathrm{C}-4, \mathrm{C}-5$, and C-6. The hydroxy proton signal at $\delta_{\mathrm{H}} 2.84$ was revealed by its ${ }^{1} \mathrm{H}^{1}{ }^{1} \mathrm{H}$ COSY correlation to $\mathrm{H}-9\left(\delta_{\mathrm{H}} 4.53\right)$ and an HMBC correlation to C-9 $\left(\delta_{\mathrm{C}} 76.9\right)$, indicating its attachment to C-9. The acetate ester at C-2 was established by a correlation between 
H-2 $\left(\delta_{\mathrm{H}} 4.86\right)$ and the acetate carbonyl at $\delta_{\mathrm{C}} 170.6$, observed in the HMBC spectrum. The methine unit at $\delta_{C} 54.9$ was more shielded than expected for an oxygenated $C$ atom and correlated with the methine proton at $\delta_{\mathrm{H}} 5.52$ in the HSQC spectrum. This proton showed a ${ }^{3} \mathrm{~J}$-correlation with $\mathrm{H}-7$, in the ${ }^{1} \mathrm{H}^{-1} \mathrm{H}$ COSY spectrum, confirming the attachment of a chlorine atom at C-6. An HMBC correlation between $\mathrm{H}-4\left(\delta_{\mathrm{H}} 4.87\right)$, an oxymethine proton, and $C-8$, an oxygenated non-protonated carbon resonating at $\delta_{C} 82.4$, suggested that the remaining oxygen atom had to be positioned between C-4 and C-8 to form an ether bridge in $\mathbf{1 .}$

Table 2. ${ }^{1} \mathrm{H}$ NMR data $(J$ in $\mathrm{Hz})$ for briaranes $\mathbf{1 - 4}$.

\begin{tabular}{|c|c|c|c|c|}
\hline Position & $1^{a}$ & $2^{a}$ & $3^{b}$ & $4^{b}$ \\
\hline 2 & $4.86 \mathrm{~d}(7.2)$ & $5.17 \mathrm{~d}(7.2)$ & $3.11 \mathrm{dd}(9.6,2.8)$ & $3.58 \mathrm{dd}(8.8,4.0)$ \\
\hline $3 \alpha$ & $\begin{array}{c}1.46 \mathrm{dd}(15.6, \\
4.2)\end{array}$ & $1.66 \mathrm{~m}$ & & \\
\hline$\beta$ & $\begin{array}{c}3.32 \text { ddd (15.6, } \\
13.2,7.2)\end{array}$ & $2.41 \mathrm{~m}$ & $3.38 \mathrm{dd}(9.2,4.0)$ & $3.33 \mathrm{dd}(8.8,4.4)$ \\
\hline $4 \alpha$ & & $2.08 \mathrm{~m}$ & & \\
\hline$\beta$ & $\begin{array}{c}4.87 \mathrm{dd}(13.2, \\
4.2)\end{array}$ & $2.01 \mathrm{~m}$ & $4.14 \mathrm{dd}(4.0,2.0)$ & $3.91 \mathrm{~d}(4.4)$ \\
\hline 6 & $5.52 \mathrm{~m}$ & 5.02 br s & $\begin{array}{c}6.03 \mathrm{ddd}(9.2,1.2, \\
1.2)\end{array}$ & $4.92 \mathrm{~d}(10.4)$ \\
\hline 7 & $4.65 \mathrm{~d}(3.0)$ & $5.35 \mathrm{~d}(1.8)$ & $5.28 \mathrm{~d}(9.2)$ & $4.71 \mathrm{~d}(10.4)$ \\
\hline 9 & $4.53 \mathrm{~d}(6.0)$ & $3.57 \mathrm{dd}(7.2,7.2)$ & $5.29 \mathrm{~d}(8.0)$ & $5.33 \mathrm{~d}(8.4)$ \\
\hline 10 & $2.08 \mathrm{~d}(12.0)$ & 2.63 br s & $1.77 \mathrm{dd}(8.0,2.8)$ & $1.82 \mathrm{dd}(8.4,2.4)$ \\
\hline 11 & $2.72 \mathrm{dq}(12.0,7.2)$ & $2.15 \mathrm{~m}$ & $2.14 \mathrm{~m}$ & $1.95 \mathrm{~m}$ \\
\hline 12 & & $4.74 \mathrm{dd}(5.4,1.8)$ & $4.71 \mathrm{~d}(4.8)$ & $4.58 \mathrm{~d}(4.8)$ \\
\hline 13 & $5.95 \mathrm{~d}(10.8)$ & $3.47 \mathrm{dd}(5.4,3.6)$ & $3.19 \mathrm{dd}(3.6,0.8)$ & $3.24 \mathrm{~d}(4.0)$ \\
\hline 14 & $6.95 \mathrm{~d}(10.8)$ & $2.88 \mathrm{~d}(3.6)$ & $3.29 \mathrm{~d}(3.6)$ & $3.27 \mathrm{~d}(4.0)$ \\
\hline 15 & $1.39 \mathrm{~s}$ & $1.30 \mathrm{~s}$ & $1.19 \mathrm{~s}$ & $1.16 \mathrm{~s}$ \\
\hline $16 a / b$ & $\begin{array}{c}5.34 \mathrm{~d}(1.8) ; 5.48 \\
\mathrm{~d}(1.8)\end{array}$ & $5.72 \mathrm{~s} ; 5.89 \mathrm{~s}$ & $\begin{array}{c}4.19 \mathrm{~d}(12.4) ; 4.09 \\
\mathrm{~d}(12.4)\end{array}$ & $5.40 \mathrm{~s} ; 5.64 \mathrm{~s}$ \\
\hline 17 & $2.53 \mathrm{q}(7.2)$ & $3.11 \mathrm{q}(7.2)$ & $2.42 \mathrm{q}(7.2)$ & $2.76 \mathrm{q}(7.2)$ \\
\hline 18 & $1.22 \mathrm{~d}(7.2)$ & $1.14 \mathrm{~d}(7.2)$ & $1.19 \mathrm{~d}(7.2)$ & $1.18 \mathrm{~d}(7.2)$ \\
\hline 20 & $1.30 \mathrm{~d}(7.2)$ & $1.05 \mathrm{~d}(7.8)$ & $1.03 \mathrm{~d}(7.2)$ & $1.01 \mathrm{~d}(7.2)$ \\
\hline $\mathrm{OH}-2$ & & & $2.43 \mathrm{~s}$ & $2.35 \mathrm{~d}(4.0)$ \\
\hline $\mathrm{OH}-8$ & & 2.86 br s & $3.12 \mathrm{~s}$ & $3.06 \mathrm{~s}$ \\
\hline $\mathrm{OH}-9$ & $2.84 \mathrm{~d}(6.0)$ & & & \\
\hline $\mathrm{OAc}-2$ & $2.15 \mathrm{~s}$ & $2.19 \mathrm{~s}$ & & \\
\hline OAc-9 & & & $2.22 \mathrm{~s}$ & $2.23 \mathrm{~s}$ \\
\hline \multirow[t]{3}{*}{ n-butyrate-12 } & & 2.34 t (7.2) & 2.35 t (7.2) & 2.35 t (7.2) \\
\hline & & 1.69 sext $(7.2)$ & 1.67 sext (7.2) & 1.67 sext $(7.2)$ \\
\hline & & 0.99 t (7.2) & 0.96 t $(7.2)$ & 0.96 t $(7.2)$ \\
\hline
\end{tabular}

a $600 \mathrm{MHz}, \mathrm{CDCl}_{3},{ }^{\mathrm{b}} 400 \mathrm{MHz}, \mathrm{CDCl}_{3}$. 

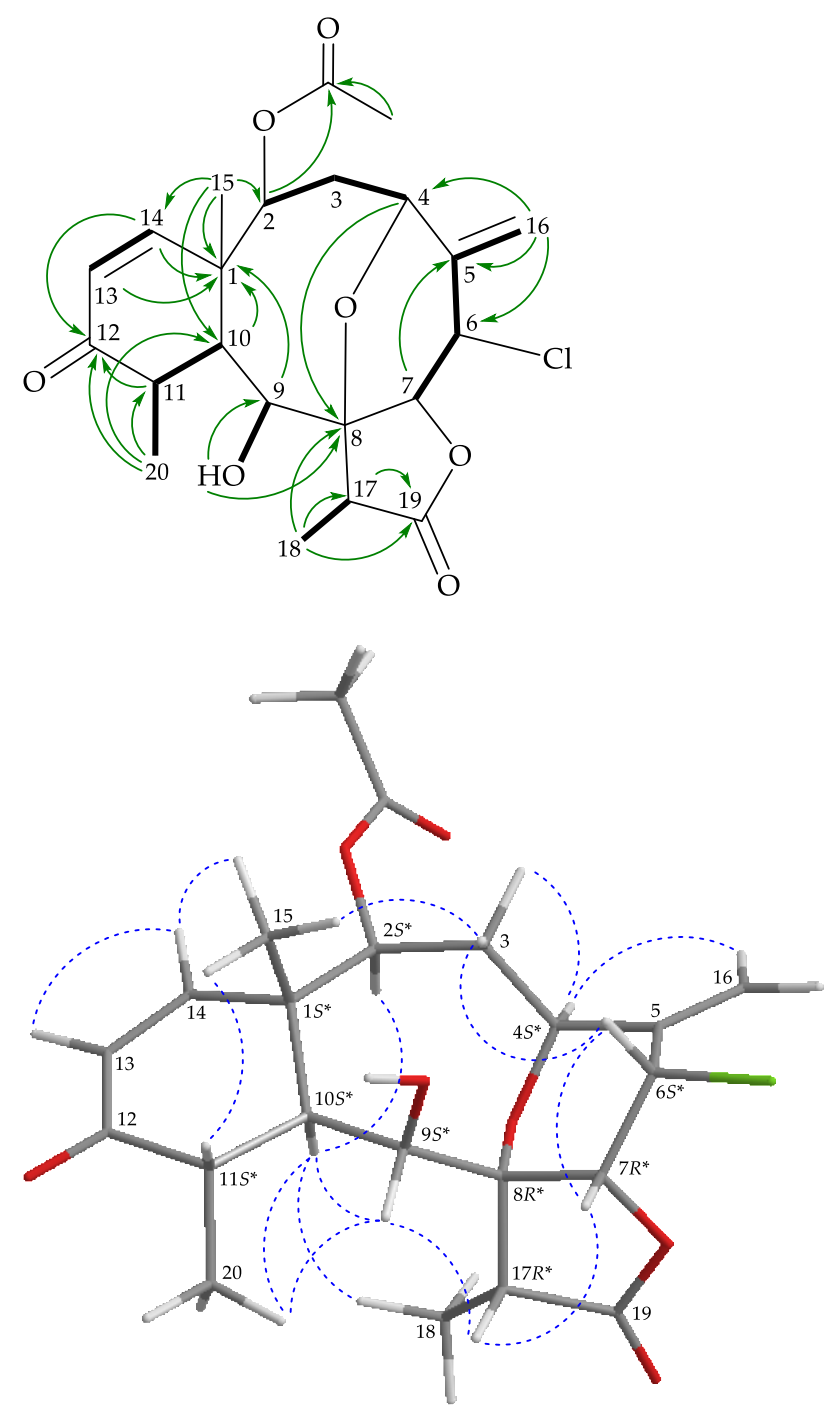

Figure 2. Key ${ }^{1} \mathrm{H}-{ }^{1} \mathrm{H}$ correlation spectroscopy (COSY) (-), heteronuclear multiple bond coherence (HMBC) $(\frown)$, and protons with nuclear Overhauser effect spectroscopy (NOESY) $(, \cdots)$ correlations for $\mathbf{1}$.

The relative stereochemistry of 1 was established using a nuclear Overhauser effect spectroscopy (NOESY) experiment (Figure 2) and was found to be compatible with that of 1 offered by basic MMX study which justifies the NOESY experiments [19]. In naturally occurring briaranes, proton $\mathrm{H}-10$ and Me-15 at C- 1 are $\alpha$ - and $\beta$-oriented, respectively [3]. $\mathrm{H}-9, \mathrm{H}-10$, and $\mathrm{H}_{3}-20$ protons were proven to be located on the same face of the molecule. These protons, as a result of being correlated together, were assigned as $\alpha$ protons, as Me-15 was a $\beta$-substituent at $\mathrm{C}-1$. Correlated with $\mathrm{H}-10$, the $\mathrm{H}-2$ proton had an $\alpha$-orientation at $\mathrm{C}-2$. Also, $\mathrm{H}_{3}-18$ was found to be associated with $\mathrm{H}-10$, suggesting that the $\mathrm{C}-18$ methyl in the $\gamma$-lactone moiety had an $\alpha$-orientation. One of the methylene protons at $C-3\left(\delta_{\mathrm{H}}\right.$ 3.32) exhibited a correlation with $\mathrm{H}_{3}-15$ and was assigned as $\mathrm{H}-3 \beta$, while the other was denoted as $\mathrm{H}-3 \alpha\left(\delta_{\mathrm{H}} 1.46\right)$. The correlations observed between $\mathrm{H}-3 \beta / \mathrm{H}-6, \mathrm{H}-6 / \mathrm{H}-7$, and $\mathrm{H}-7 / \mathrm{H}-17$ reflected the $\beta$-orientation of both protons at C- 6 and C-7. The cis geometry of the C-13/14 double bond was indicated by a $10.8 \mathrm{~Hz}$ coupling constant between $\mathrm{H}-13\left(\delta_{\mathrm{H}}\right.$ 5.95) and H-14 ( $\delta_{\mathrm{H}}$ 6.95), and further confirmed by a NOESY correlation between these two olefinic protons. Furthermore, $\mathrm{H}-3 \alpha$ showed a correlation with $\mathrm{H}-4$, demonstrating the $S^{*}$-configuration of stereogenic center C-4. The remaining stereogenic carbon, C-8, lacked a proton but there were correlations between $\mathrm{H}-9 / \mathrm{H}-17$ and $\mathrm{H}-7 / \mathrm{H}-17$, indicating that C-8 was in an $R^{*}$-configuration, as evidenced by modeling analysis. Based on the 
above findings, the configuration of the stereogenic centers of 1 was assigned as $\left(1 S^{*}, 2 S^{*}\right.$, $4 S^{*}, 6 S^{*}, 7 R^{*}, 8 R^{*}, 9 S^{*}, 10 S^{*}, 11 S^{*}, 17 R^{*}$ ) (Supplementary Materials, Figures S1-S11).

Briarenol X (2) had the molecular formula $\mathrm{C}_{26} \mathrm{H}_{37} \mathrm{ClO}_{9}$ on the basis of (+)-HRESIMS at $m / z 551.20198$ (calculated for $\mathrm{C}_{26} \mathrm{H}_{37} \mathrm{ClO}_{9}+\mathrm{Na}, 551.20183$ ). The IR spectrum of 2 showed bands at 3484, 1777, and $1729 \mathrm{~cm}^{-1}$, consistent with the presence of hydroxy, $\gamma$-lactone, and ester carbonyl groups, respectively. ${ }^{13} \mathrm{C}$ NMR and DEPT spectroscopic data (Table 1) revealed that 2 contained an exocyclic carbon-carbon double bond $\left(\delta_{C} 140.3, C-5\right.$; 118.6, $\left.\mathrm{CH}_{2}-16\right)$ and three carbonyl resonances $\left(\delta_{C} 176.4,173.3\right.$, and 168.3). Two esters were identified as acetate and $n$-butyrate respectively by the presence of resonances in the ${ }^{1} \mathrm{H}$ NMR spectrum of 2 at $\delta_{\mathrm{H}} 2.19(3 \mathrm{H}, \mathrm{s}), 0.99(3 \mathrm{H}, \mathrm{t}, J=7.2 \mathrm{~Hz}), 1.69(2 \mathrm{H}, \mathrm{sext}, J=7.2 \mathrm{~Hz})$, and $2.34(2 \mathrm{H}, \mathrm{t}, J=7.2 \mathrm{~Hz})$ (Table 2$)$.

In the HMBC spectrum of 2 (Figure 3), the $n$-butyrate positioned at $C-12$ was confirmed from the long-range coupling between $\mathrm{H}-12\left(\delta_{\mathrm{H}} 4.74\right)$ with the carbonyl carbon $\left(\delta_{\mathrm{C}} 173.3\right)$ of the $n$-butyroxy group. The HMBC correlation also revealed that one acetate was attached to $\mathrm{C}-2$. These data, together with the other ${ }^{1} \mathrm{H}_{-}{ }^{13} \mathrm{C}$ long-range correlations, unambiguously established the molecular framework of $\mathbf{2}$. According to the above observations, metabolite 2 seemed to be very similar to solenolide A (5) [15], which was previously isolated from an octocoral Solenopodium sp. By means of 1D and 2D NMR data it was found that the $n$-hexanoate group at C-12 position in solenolide A (5) was replaced by an $n$-butyrate group in 2.
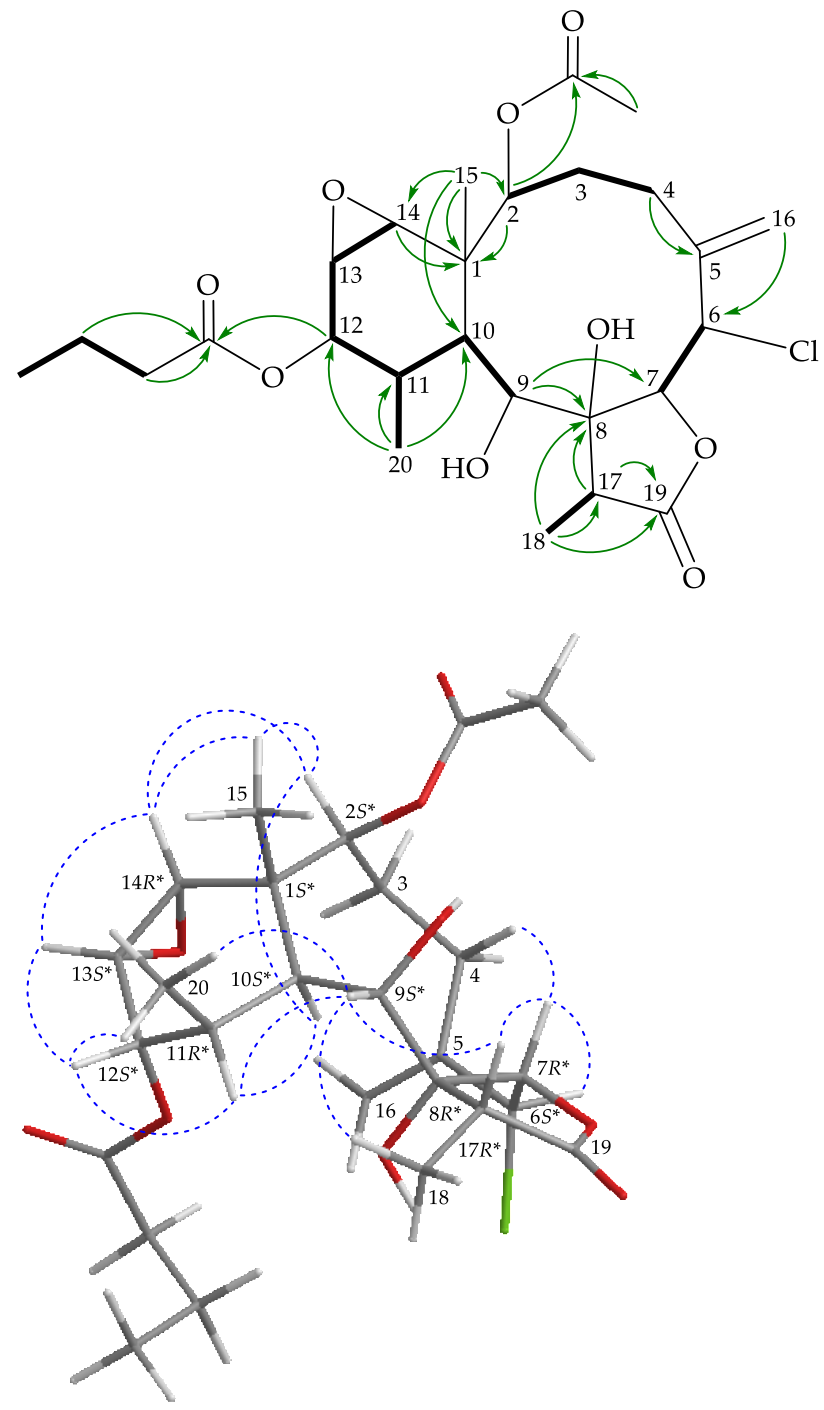

Figure 3. Key COSY $(-), \operatorname{HMBC}(\ulcorner)$, and protons with $\operatorname{NOESY}(, \cdots)$ ) correlations for 2. 
The relative configuration of 2 was determined by NOESY analysis (Figure 3). The NOESY correlations between $\mathrm{H}-10 / \mathrm{H}-11$ and $\mathrm{H}-10 / \mathrm{H}-2$ required that all of these groups were in $\alpha$-face and correlations of $\mathrm{H}_{3}-15 / \mathrm{H}-14, \mathrm{H}-14 / \mathrm{H}-13$, and $\mathrm{H}-13 / \mathrm{H}-12$ indicated $\beta$-disposition for these groups. The correlations between $\mathrm{H}-9 / \mathrm{H}-11, \mathrm{H}-9 / \mathrm{H}_{3}-18$, and $\mathrm{H}-9 / \mathrm{H}-7$ suggested that $\mathrm{H}-9$ and $\mathrm{H}_{3}-18$ were $\alpha$-oriented and $\mathrm{H}-7$ was $\beta$-oriented from modeling analysis. A correlation between $\mathrm{H}-6$ and $\mathrm{H}-7$ reflected the $\beta$-orientation of protons at C-6. The negative optical rotation value of $2\left([\alpha]_{\mathrm{D}}^{20}-14\left(c 0.05, \mathrm{CHCl}_{3}\right)\right)$ was similar to that of 5 (solenolide A) $\left([\alpha]_{\mathrm{D}}^{20}-28\left(c 0.04, \mathrm{CHCl}_{3}\right)\right.$; reference $[15],[\alpha]_{\mathrm{D}}^{20}$ $\left.-56\left(c 0.63, \mathrm{CHCl}_{3}\right)\right)$ that was also obtained in this study, suggesting that 2 and 5 had $1 S^{*}, 10 S^{*}$-configurations in the ring junction. Based on the above findings, the structure of 2, including the relative configuration, was elucidated ambiguously, and its stereogenic centers were assigned as $\left(1 S^{*}, 2 S^{*}, 6 S^{*}, 7 R^{*}, 8 R^{*}, 9 S^{*}, 10 S^{*}, 11 R^{*}, 12 S^{*}, 13 S^{*}, 14 R^{*}, 17 R^{*}\right)$ (Supplementary Materials, Figures S12-S22).

Briarane 3 (briarenol Y) was isolated as an amorphous powder that showed two sodiated adduct ion peaks in (+)-HRESIMS at $m / z 565.18106[\mathrm{M}+\mathrm{Na}]^{+}$and 567.17800 $[\mathrm{M}+2+\mathrm{Na}]^{+}(3: 1)$, which accounted for a chlorine atom in the molecular formula, $\mathrm{C}_{26} \mathrm{H}_{35} \mathrm{ClO}_{10}$ (calculated for $\mathrm{C}_{26} \mathrm{H}_{35}{ }^{35} \mathrm{ClO}_{10}+\mathrm{Na}, 565.18110$ ). Its absorption peaks in the IR spectrum showed ester carbonyl, $\gamma$-lactone, and broad $\mathrm{OH}$ stretching at 1738, 1778, and $3459 \mathrm{~cm}^{-1}$, respectively. From the ${ }^{13} \mathrm{C}$ and ${ }^{1} \mathrm{H}$ NMR (Tables 1 and 2), three carbonyl resonances at $\delta_{\mathrm{C}} 175.5(\mathrm{C}-19), 173.1$, and 169.5 confirmed the presence of a $\gamma$-lactone and two ester groups; an acetate methyl $\left(\delta_{\mathrm{H}} 2.22,3 \mathrm{H}, \mathrm{s}\right)$ and an $n$-butyrate $\left(\delta_{\mathrm{H}} 2.35,2 \mathrm{H}, \mathrm{t}\right.$, $J=7.2 \mathrm{~Hz} ; 1.67,2 \mathrm{H}$, sext, $J=7.2 \mathrm{~Hz} ; 0.96,3 \mathrm{H}, \mathrm{t}, J=7.2 \mathrm{~Hz}$ ) were also observed. Two disubstituted epoxy groups were deduced from the signals of four oxymethine carbons at $\delta_{\mathrm{C}} 62.1(\mathrm{CH}-14), 60.5(\mathrm{CH}-3), 58.1(\mathrm{CH}-4)$, and $57.2(\mathrm{CH}-13)$. The chemical shifts of oxymethine protons at $\delta_{\mathrm{H}} 3.29(1 \mathrm{H}, \mathrm{d}, J=3.6 \mathrm{~Hz}, \mathrm{H}-14), 3.38(1 \mathrm{H}, \mathrm{dd}, J=9.2,4.0 \mathrm{~Hz}, \mathrm{H}-3)$, $4.14(1 \mathrm{H}, \mathrm{dd}, J=4.0,2.0 \mathrm{~Hz}, \mathrm{H}-4)$, and $3.19(1 \mathrm{H}, \mathrm{dd}, J=3.6,0.8 \mathrm{~Hz}, \mathrm{H}-13)$ further confirmed the presence of these two groups. Based on the ${ }^{13} \mathrm{C}$ NMR data and degrees of unsaturation, 3 was established as a pentacyclic diterpenoid. It was found that the ${ }^{1} \mathrm{H}$ and ${ }^{13} \mathrm{C}$ NMR data of 3 resembled those of a known briarane, briarenolide $M$ (6) (Figure 1) [16], except that the signals corresponding to the C-12 acetoxy group in 6 were replaced by signals for an n-butyroxy group in 3 . Locations of the functional groups were confirmed by other HMBC and COSY correlations (Figure 4).

The relative configuration of $\mathbf{3}$ was determined from the NOESY spectrum (Figure 4), which showed NOESY correlations among the corresponding protons similar to those of 6 [16]. The negative optical rotation value of $3\left([\alpha]_{\mathrm{D}}^{24}-73\left(c 0.1, \mathrm{CHCl}_{3}\right)\right)$ was similar to that of $6\left([\alpha]_{\mathrm{D}}^{25}-58\left(c 0.7, \mathrm{CHCl}_{3}\right)\right)$ [16] in direction and magnitude, suggesting that 3 and 6 had $1 S^{*}, 10 S^{*}$-configurations in the ring junction. Thus, briarenol $Y$ was assigned as the structure of 3 and the configurations of the stereogenic carbons were elucidated as $\left(1 S^{*}, 2 R^{*}, 3 S^{*}, 4 R^{*}, 7 S^{*}, 8 R^{*}, 9 S^{*}, 10 S^{*}, 11 R^{*}, 12 R^{*}, 13 S^{*}, 14 R^{*}, 17 R^{*}\right)$ (Supplementary Materials, Figures S23-S33).

Briarane 4 (briarenol Z) was isolated as an amorphous powder and had the molecular formula $\mathrm{C}_{26} \mathrm{H}_{35} \mathrm{ClO}_{10}$ on the basis of (+)-HRESIMS (see Materials and Methods section). The IR spectrum of 4 showed bands at 3450,1777, and $1736 \mathrm{~cm}^{-1}$, consistent with the presence of hydroxy, $\gamma$-lactone, and ester carbonyl groups. It was found that the spectroscopic data of 4 were very similar to those of a known briarane metabolite, briaexcavatolide $\mathrm{F}$ (7) [17]. However, a comparison of the ${ }^{1} \mathrm{H}$ and ${ }^{13} \mathrm{C}$ NMR chemical shifts of C-6 methine $\left(\delta_{\mathrm{H}} 4.92,1 \mathrm{H}, \mathrm{d}, J=10.4 \mathrm{~Hz} ; \delta_{\mathrm{C}} 63.2\right), \mathrm{C}-7$ oxymethine $\left(\delta_{\mathrm{H}} 4.71,1 \mathrm{H}, \mathrm{d}, J=10.4 \mathrm{~Hz} ; \delta_{\mathrm{C}} 83.0\right)$, and C-5 sp $\mathrm{sp}^{2}$ non-protonated carbon $\left(\delta_{\mathrm{C}}\right.$ 137.4) of 4 (Tables 1 and 2) with those of $7\left(\delta_{\mathrm{H}}\right.$ $5.83,1 \mathrm{H}, \mathrm{d}, J=3.3 \mathrm{~Hz} ; \delta_{\mathrm{C}} 61.8, \mathrm{CH}-6 ; \delta_{\mathrm{H}} 5.73,1 \mathrm{H}, \mathrm{d}, J=3.3 \mathrm{~Hz} ; \delta_{\mathrm{C}} 79.8, \mathrm{CH}-7 ; \delta_{\mathrm{C}} 138.7$, C-5) [17] showed that H-6 in 4 was $\alpha$-oriented. The NOESY spectrum exhibited a strong correlation from $\mathrm{H}-7$ to $\mathrm{H}-4$, but not with $\mathrm{H}-6$ (Figure 5), and a large vicinal proton coupling constant $(J=10.4 \mathrm{~Hz})$ was detected between $\mathrm{H}-7$ and $\mathrm{H}-6$, indicating that the dihedral angle between H-6 and H-7 was approximately $180^{\circ}$, that $\mathrm{H}-6$ was $\alpha$-oriented in 4 , and that this compound should possess a structure as represented by formula 4 . The structure of 4 
was further confirmed by 2D NMR experiments (Figure 5 ) and its stereogenic centers were assigned as $\left(1 S^{*}, 2 R^{*}, 3 S^{*}, 4 R^{*}, 6 R^{*}, 7 R^{*}, 8 R^{*}, 9 S^{*}, 10 S^{*}, 11 R^{*}, 12 R^{*}, 13 S^{*}, 14 R^{*}, 17 R^{*}\right)$ by NOESY experiment (Figure 5) (Supplementary Materials, Figures S34-S44).
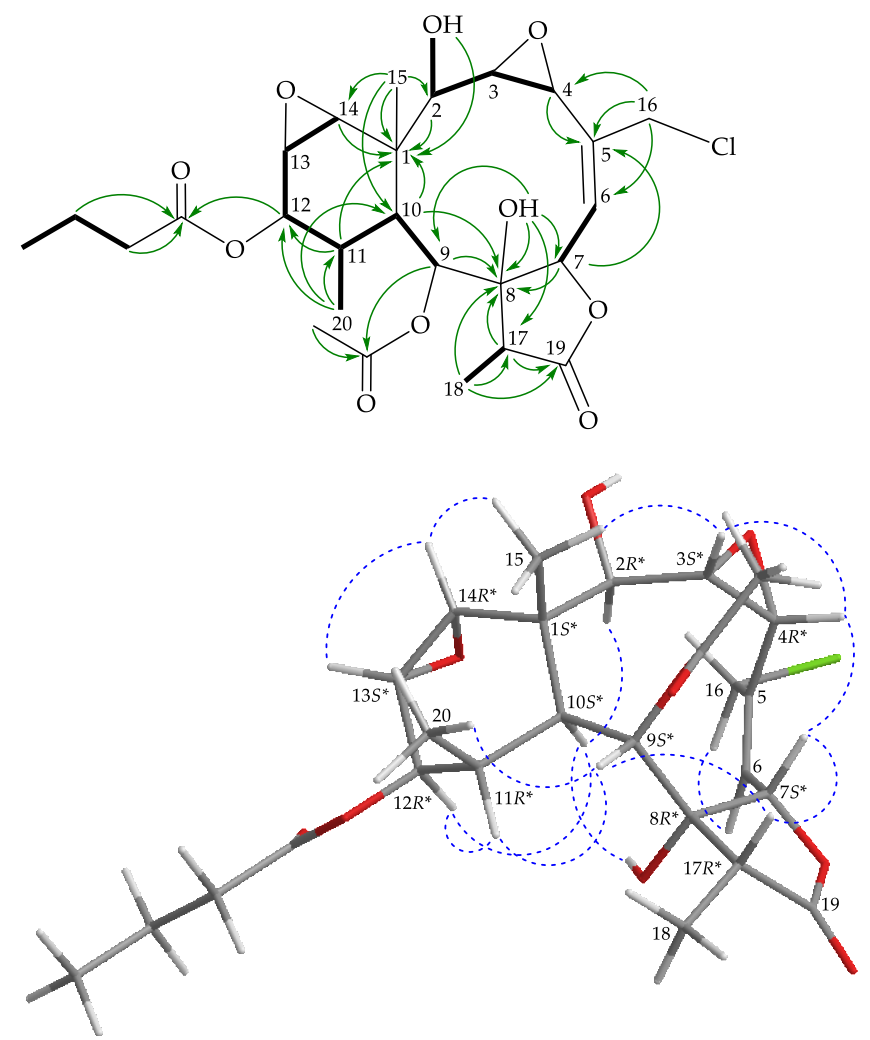

Figure 4. Key $\operatorname{COSY}(-), \operatorname{HMBC}(\neg)$, and protons with $\operatorname{NOESY}(, \cdots)$ ) correlations for 3.
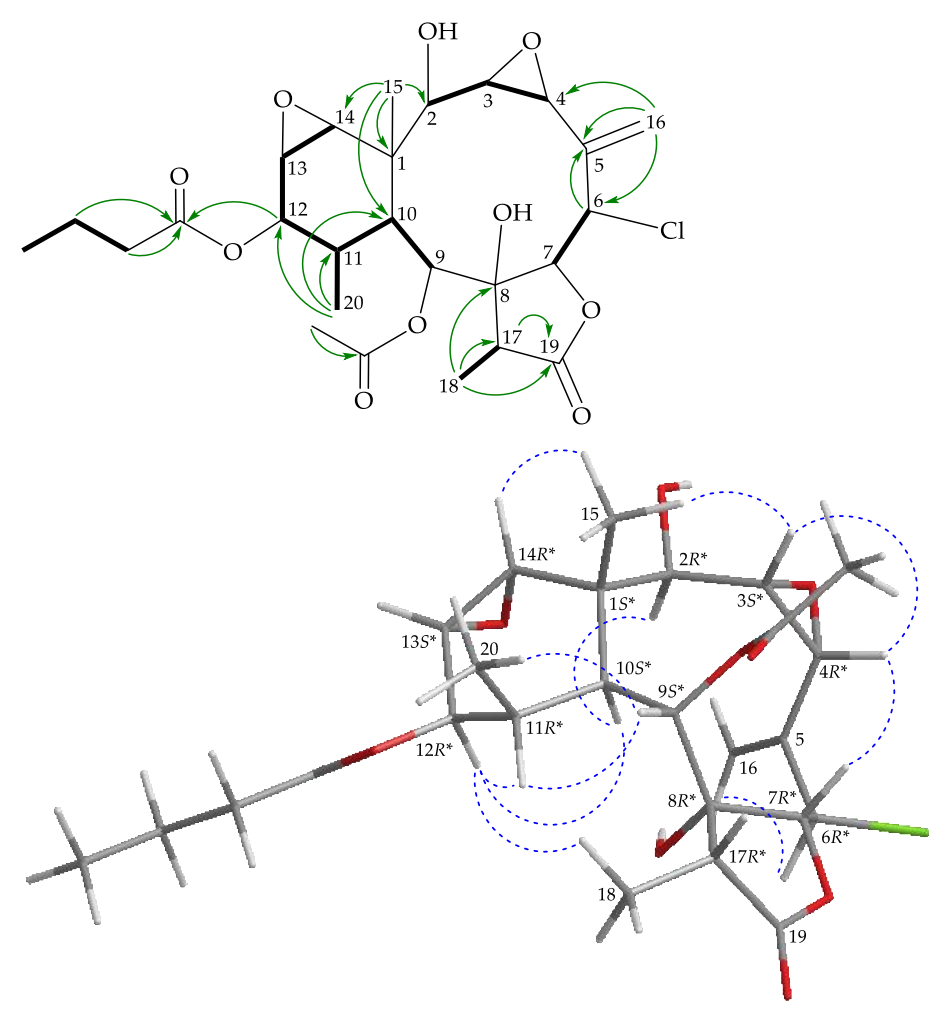

Figure 5. Key COSY $(-), \operatorname{HMBC}(\frown)$, and protons with $\operatorname{NOESY}(, \cdots)$ ) correlations for 4. 
Known briaranes 5-8 were found to be identical with briarenolide solenolide A [15], briarenolide M [16], briaexcavatolide F [17], and brianolide [18], respectively by comparison of the spectroscopic data with those reported previously.

A single-crystal x-ray diffraction was used to confirm the structure of brianolide 8 . The Oak Ridge Thermal Ellipsoid Plot (ORTEP) diagram (Figure 6) showed that the absolute configurations of the stereogenic carbons of 8 were confirmed as $(1 S, 2 R, 3 S, 4 R, 6 S, 7 R$, $8 R, 9 S, 10 S, 11 R, 12 R, 13 S, 14 R, 17 R$ ) (Flack parameter $\mathrm{x}=0.095(8)$ ).

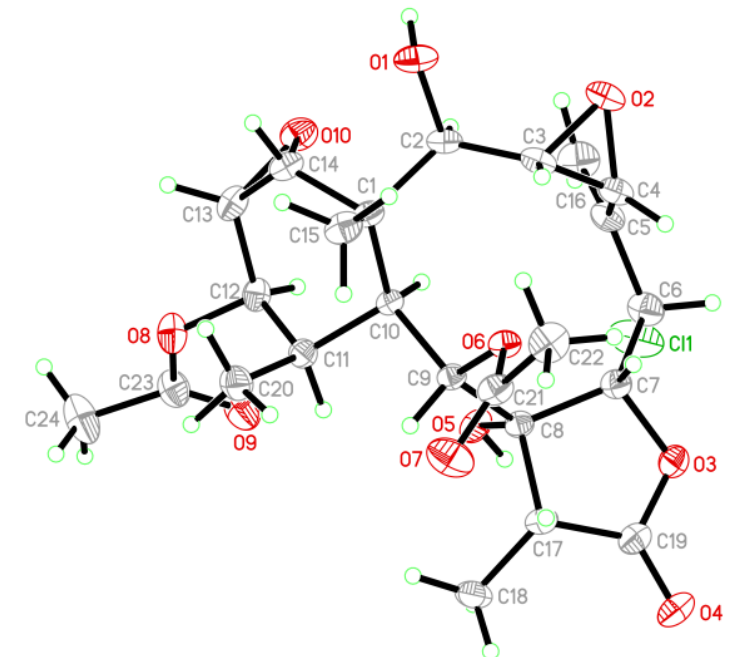

Figure 6. Oak Ridge Thermal Ellipsoid Plot (ORTEP) plot revealing the absolute configuration of 8 (methanol molecule has been omitted for clarify).

\subsection{Bioactivity of Isolated Briaranes}

It is well documented that the microbial lipopolysaccharide (LPS) can activate tolllike receptor-4 (TLR-4), located in the mammal cell membrane surface, which triggers inflammatory responses through the activation of intracellular signal transduction and the upregulation of pro-inflammatory proteins inducible nitric oxide synthase (iNOS) and cyclooxygenase-2 (COX-2) [20]. It is well known that inhibition of the expression of pro-inflammatory proteins iNOS and COX-2 in LPS-stimulated macrophage cells can be used as for in vitro screening of anti-inflammatory compounds [21-23]. The massive production of inflammatory mediators, nitric oxide (NO) and prostaglandin E2 (PGE2) via pro-inflammatory proteins iNOS and COX-2, respectively, plays an important pathophysiological role in inflammation. There are two COX isozymes, COX-1 (cyclooxygenase-1) and COX-2, catalyzing the prostaglandin synthesis. COX-1 is constitutively expressed in normal physiological conditions. Unlike COX-1, COX-2 is an inducible enzyme that increases following injury or inflammation [24,25]. COX-2 plays a more vital role in pathology than COX-1 under inflammatory processions.

The effects of briaranes 1-7 on the release of iNOS and COX-2 from LPS-stimulated RAW 264.7 macrophage cells were assessed (Table 3). Briaranes 2 and 5 at $10 \mu \mathrm{M}$ enhanced the release of iNOS (142.03 and 134.11\%, respectively) and COX-2 (159.21 and $196.03 \%$, respectively) as compared to results for the cells stimulated with LPS only. It is interesting to note that these findings seem to be contrary to results claimed to show that most briarane-type natural products from octocorals are anti-inflammatory [26]. Structureactivity relationships among these marine diterpenoids will be evaluated if enough materials are obtained. 
Table 3. Effects of briaranes 1-7 on lipopolysaccharide (LPS)-induced pro-inflammatory inducible nitric oxide synthase (iNOS) and cyclooxygenase-2 (COX-2) protein expressions in macrophages.

\begin{tabular}{cccc}
\hline Compound & iNOS & COX-2 & $\beta$-Actin \\
\hline $\mathbf{1 0} \boldsymbol{\mu M}$ & \multicolumn{3}{c}{ Expression $\mathbf{( \% \text { of LPS } )}$} \\
\hline Control & $2.88 \pm 0.86$ & $0.94 \pm 0.10$ & $107.01 \pm 2.73$ \\
Vehicle & $88.00 \pm 1.84 \pm 12.38$ & $100.00 \pm 3.98$ & $100.00 \pm 1.66$ \\
1 & $142.03 \pm 18.44$ & $103.23 \pm 5.20$ & $101.63 \pm 4.23$ \\
2 & $99.71 \pm 13.77$ & $89.20 \pm 1.40$ & $97.81 \pm 3.15$ \\
3 & $103.25 \pm 16.72$ & $96.92 \pm 4.72$ & $98.31 \pm 5.33$ \\
4 & $134.11 \pm 14.70$ & $196.03 \pm 12.35$ & $106.56 \pm 1.98$ \\
5 & $86.20 \pm 11.20$ & $85.98 \pm 2.47$ & $104.50 \pm 2.01$ \\
6 & $92.55 \pm 10.52$ & $91.71 \pm 1.90$ & $104.80 \pm 2.53$ \\
7 & $61.24 \pm 11.09$ & $18.17 \pm 2.65$ & $104.70 \pm 3.83$ \\
\hline
\end{tabular}

Data were normalized to those of cells treated with LPS alone and cells treated with dexamethasone were used as a positive control. Data are expressed as the mean \pm SEM. The $\beta$-actin of Western blotting was used for loading/internal control.

\section{Materials and Methods}

\subsection{General Experimental Procedures}

A digital polarimeter (model P-1010; JASCO Corp., Tokyo, Japan) was used to determine optical rotations of the samples. IR spectra were collected using a spectrophotometer (model Nicolet iS5 FT-IR; Thermo Fisher Scientific, Waltham, MA, USA). ${ }^{1} \mathrm{H}$ and ${ }^{13} \mathrm{C}$ NMR spectra were recorded on ECZ-400 or ECZ-600 spectrometers (Jeol Ltd., Tokyo, Japan) for solutions in $\mathrm{CDCl}_{3}$ (with residual $\mathrm{CHCl}_{3}\left(\delta_{\mathrm{H}} 7.26 \mathrm{ppm}\right)$ and $\mathrm{CDCl}_{3}\left(\delta_{\mathrm{C}} 77.0 \mathrm{ppm}\right)$ as internal standards). For coupling constants (J), the results were given in frequency units $(\mathrm{Hz})$. For positive mode ESIMS and HRESIMS, the results were obtained using a SolariX FTMS mass spectrometer (7 Tesla; Bruker, Bremen, Germany). The extracted samples were separated by column chromatography with silica gel (between 230 and 400 meshes; Merck). Thin-layer chromatography plates with silica gel coated with fluorescent indicator $\mathrm{F}_{254}$ were employed. For visualization, the plates were charred with $10 \%(v / v)$ aqueous sulfuric acid solution, then heated at $105{ }^{\circ} \mathrm{C}$ until spots were seen. For normal-phase HPLC separation, a system containing a pump (Hitachi model L-7110; Tokyo, Japan) and an injection interface (No. 7725; Rheodyne) was employed, equipped with a semi-preparative column with dimensions of $250 \times 20 \mathrm{~mm}$ and a $5-\mu \mathrm{m}$ particle size (Sigma). For reverse-phase HPLC separation, a system composed of a pump (Hitachi model L-2130) and a diode-array detector (LaChrom L-2455, Hitachi) was used, equipped with a column with dimensions of $2.1 \times 25 \mathrm{~cm}$ and a $5-\mu \mathrm{m}$ particle size (Phenomenex).

\subsection{Animal Material}

Specimens of B. stechei used for this study were collected from an 80-ton culturing tank equipped with a flow-through seawater system located in the National Museum of Marine Biology and Aquarium (NMMBA) in April 2016. Identification of the species of this organism was performed by comparison, as described in previous studies [14]. Living reference specimens are maintained in the authors' marine organism culturing tanks and a voucher specimen was deposited with the NMMBA (voucher no.: NMMBA-TW-GC-2016031), Taiwan.

\subsection{Extraction and Isolation}

Sliced bodies (wet $/$ dry weight $=3980 / 1860 \mathrm{~g}$ ) of the specimen were grounded and extracted with a mixture of $\mathrm{MeOH}$ and $\mathrm{CH}_{2} \mathrm{Cl}_{2}$ (1:1) to provide an extract (104 g). The extract was then applied to a silica gel column chromatography (Si C.C.) and eluted with gradients of $n$-hexane/EtOAc (stepwise from 50:1-1:2) to furnish fractions A-L. Fractions $\mathrm{H}$ and I were combined $(19.0 \mathrm{~g})$ and washed with acetone to obtain an undissolved material brianolide (8) (2.59 g). The dissolved material was separated with Si C.C. using 
n-hexane/EtOAc (stepwise from 50:1-pure EtOAc) to obtain fractions $\mathrm{H} 1-\mathrm{H} 8$. Fraction H6 was chromatographed with Si C.C. using $n$-hexane/EtOAc/acetone to obtain fractions H6A-H6K. Fraction H6E was separated by Si C.C. using a mixture of $\mathrm{CH}_{2} \mathrm{Cl}_{2}$ and acetone (4:1) to obtain fractions H6E1-H6E6. Fraction H6E1 was repurified by RP-HPLC using a mixture of $\mathrm{MeOH}$ and $\mathrm{H}_{2} \mathrm{O}(7: 3)$ to yield fractions H6E1A-H6E1K. H6E1K was separated by RP-HPLC using a mixture of $\mathrm{MeOH}$ and $\mathrm{H}_{2} \mathrm{O}(8: 2$; at a flow rate $=4.0 \mathrm{~mL} / \mathrm{min})$ to yield briarenol X (2) (0.9 mg). Fraction H6E2 was separated by NP-HPLC using a mixture of $\mathrm{CH}_{2} \mathrm{Cl}_{2}$ and acetone (8:1) to yield fractions H6E2A-H6E2E. Fraction H6E2A was repurified by RP-HPLC using a mixture of $\mathrm{MeOH}$ and $\mathrm{H}_{2} \mathrm{O}$ (7:3) to yield fractions H6E2A1-H6E2A6. Fraction H6E2A5 was further separated by RP-HPLC with a mixture of $\mathrm{MeOH}$ and $\mathrm{H}_{2} \mathrm{O}$ (7:3) to yield fractions H6E2A5A-H6E2A5E. Fraction H6E2A5E was separated by RP$\mathrm{HPLC}$ with a mixture of $\mathrm{MeOH}$ and $\mathrm{H}_{2} \mathrm{O}(8: 2$; at a flow rate $=4.0 \mathrm{~mL} / \mathrm{min})$ to yield solenolide A (5) $(0.6 \mathrm{mg})$. Fraction H6E3 was repurified by NP-HPLC using a mixture of $\mathrm{CH}_{2} \mathrm{Cl}_{2}$ and acetone (9:1) to yield fractions H6E3A-H6E3G. Fraction H6E3D was separated by RP-HPLC using a mixture of $\mathrm{MeOH}$ and $\mathrm{H}_{2} \mathrm{O}(7: 3$; at a flow rate $=5.0 \mathrm{~mL} / \mathrm{min})$ to yield briarenols W (1) (0.6 mg), Y (3) (2.8 mg), and Z (4) (1.2 mg), respectively. Fraction H6E4 was separated by NP-HPLC using a mixture of $\mathrm{CH}_{2} \mathrm{Cl}_{2}$ and acetone (6:1) to obtain fractions H6E4A-H6E4I. Fraction H6E4E was repurified by NP-HPLC using a mixture of $n$-hexane and acetone (5:2) to obtain fractions H6E4E1-H6E4E10. Fraction H6E4E8 was separated by RP-HPLC with a mixture of $\mathrm{MeOH}$ and $\mathrm{H}_{2} \mathrm{O}(7: 3$; at a flow rate $=5.0 \mathrm{~mL} / \mathrm{min})$ to yield briarenolide $\mathrm{M}(6)$ (4.5 mg). Fraction H6F was separated by RP-HPLC with a mixture of $\mathrm{MeOH}$ and $\mathrm{H}_{2} \mathrm{O}(7: 3$; at a flow rate $=5.0 \mathrm{~mL} / \mathrm{min})$ to yield briaexcavatolide $\mathrm{F}(7)(8.9 \mathrm{mg})$.

Briarenol W (1): amorphous powder; $[\alpha]_{\mathrm{D}}^{24}-29\left(c 0.1, \mathrm{CHCl}_{3}\right)$; IR $(\mathrm{KBr}) v_{\max } 3430$, $1780,1733,1670 \mathrm{~cm}^{-1} ;{ }^{13} \mathrm{C}\left(150 \mathrm{MHz}, \mathrm{CDCl}_{3}\right)$ and ${ }^{1} \mathrm{H}\left(600 \mathrm{MHz}, \mathrm{CDCl}_{3}\right) \mathrm{NMR}$ data, see Tables 1 and 2; ESIMS: $m / z 461[\mathrm{M}+\mathrm{Na}]^{+}, 463[\mathrm{M}+2+\mathrm{Na}]^{+}$; HRESIMS: $m / z 461.13377$ (calculated for $\mathrm{C}_{22} \mathrm{H}_{27}{ }^{35} \mathrm{ClO}_{7}+\mathrm{Na}, 461.13375$ ).

Briarenol X (2): amorphous powder; $[\alpha]_{\mathrm{D}}^{24}-14\left(\right.$ c 0.05, $\left.\mathrm{CHCl}_{3}\right)$; IR (ATR) $v_{\max } 3484$, 1777, $1729 \mathrm{~cm}^{-1} ;{ }^{13} \mathrm{C}\left(150 \mathrm{MHz}, \mathrm{CDCl}_{3}\right)$ and ${ }^{1} \mathrm{H}\left(600 \mathrm{MHz}, \mathrm{CDCl}_{3}\right) \mathrm{NMR}$ data, see Tables 1 and 2; ESIMS: $m / z 551[\mathrm{M}+\mathrm{Na}]^{+}, 553[\mathrm{M}+2+\mathrm{Na}]^{+}$; HRESIMS: $m / z 551.20198$ (calculated for $\mathrm{C}_{26} \mathrm{H}_{37}{ }^{35} \mathrm{ClO}_{9}+\mathrm{Na}, 551.20183$ ).

Briarenol Y (3): amorphous powder; $[\alpha]_{\mathrm{D}}^{24}-73\left(c 0.1, \mathrm{CHCl}_{3}\right)$; IR $(\mathrm{KBr}) v_{\max } 3459,1778$, $1738 \mathrm{~cm}^{-1} ;{ }^{13} \mathrm{C}\left(100 \mathrm{MHz}, \mathrm{CDCl}_{3}\right)$ and ${ }^{1} \mathrm{H}\left(400 \mathrm{MHz}, \mathrm{CDCl}_{3}\right) \mathrm{NMR}$ data, see Tables 1 and 2; ESIMS: $m / z 565[\mathrm{M}+\mathrm{Na}]^{+}, 567\left[\mathrm{M}+2+\mathrm{Na}^{+}\right.$; HRESIMS: $m / z 565.18106$ (calculated for $^{2}$ $\left.\mathrm{C}_{26} \mathrm{H}_{35}{ }^{35} \mathrm{ClO}_{10}+\mathrm{Na}, 565.18110\right)$.

Briarenol Z (4): amorphous powder; $[\alpha]_{\mathrm{D}}^{24}-12\left(c 0.2, \mathrm{CHCl}_{3}\right)$; IR $(\mathrm{KBr}) v_{\max } 3450,1777$, $1736 \mathrm{~cm}^{-1} ;{ }^{13} \mathrm{C}\left(100 \mathrm{MHz}, \mathrm{CDCl}_{3}\right)$ and ${ }^{1} \mathrm{H}\left(400 \mathrm{MHz}, \mathrm{CDCl}_{3}\right) \mathrm{NMR}$ data, see Tables 1 and 2; ESIMS: $m / z 565[\mathrm{M}+\mathrm{Na}]^{+}, 567[\mathrm{M}+2+\mathrm{Na}]^{+}$; HRESIMS: $m / z 565.18137$ (calculated for $\left.\mathrm{C}_{26} \mathrm{H}_{35}{ }^{35} \mathrm{ClO}_{10}+\mathrm{Na}, 565.18110\right)$.

Solenolide A (5): amorphous powder; $[\alpha]_{\mathrm{D}}^{25}-28\left(c 0.04, \mathrm{CHCl}_{3}\right)$ (reference [15], [ $\left.\alpha\right]_{\mathrm{D}}^{20}$ $-56\left(c 0.63, \mathrm{CHCl}_{3}\right)$ ); the ${ }^{1} \mathrm{H}$ and ${ }^{13} \mathrm{C} \mathrm{NMR}$ data of 5 are in full agreement with those reported previously [15]; ESIMS: $m / z 579[\mathrm{M}+\mathrm{Na}]^{+}, 581[\mathrm{M}+2+\mathrm{Na}]^{+}$.

Briarenolide $\mathrm{M}(6)$ : amorphous powder; $[\alpha]_{\mathrm{D}}^{24}-81\left(c 0.3, \mathrm{CHCl}_{3}\right)$ (reference [16], $[\alpha]_{\mathrm{D}}^{25}$ $\left.-58\left(c 0.7, \mathrm{CHCl}_{3}\right)\right)$; the ${ }^{1} \mathrm{H}$ and ${ }^{13} \mathrm{C}$ NMR data of 6 are in full agreement with those reported previously [16]; ESIMS: $m / z 537[\mathrm{M}+\mathrm{Na}]^{+}, 539[\mathrm{M}+2+\mathrm{Na}]^{+}$.

Briaexcavatolide $\mathrm{F}(7)$ : amorphous powder; $[\alpha]_{\mathrm{D}}^{26}-14(c 0.1, \mathrm{MeOH})$ (reference [17], $\left.[\alpha]_{\mathrm{D}}^{25}-21(c \mathrm{0.1}, \mathrm{MeOH})\right)$; the ${ }^{1} \mathrm{H}$ and ${ }^{13} \mathrm{C}$ NMR data of 7 are in full agreement with those reported previously [17]; ESIMS: $m / z 565[\mathrm{M}+\mathrm{Na}]^{+}, 567[\mathrm{M}+2+\mathrm{Na}]^{+}$.

Brianolide (8): colorless prisms; $[\alpha]_{\mathrm{D}}^{26}-25\left(\right.$ c 2.3, $\left.\mathrm{CHCl}_{3}\right)$ (reference [18], $[\alpha]_{\mathrm{D}}^{23}-15$ (c $0.1, \mathrm{MeOH})$ ); the ${ }^{1} \mathrm{H}$ and ${ }^{13} \mathrm{C}$ NMR data of 8 are in full agreement with those reported previously [18]; ESIMS: $m / z 537[\mathrm{M}+\mathrm{Na}]^{+}, 539[\mathrm{M}+2+\mathrm{Na}]^{+}$.

\subsection{Single-Crystal X-Ray Crystallography of Brianolide (8)}

Suitable colorless prisms of $\mathbf{1}$ were obtained from a solution of $\mathrm{MeOH}$. The crystal $\left(0.158 \times 0.108 \times 0.108 \mathrm{~mm}^{3}\right)$ belongs to the tetragonal system, space group $P 4_{1} 2_{1} 2$ 
(\#92), with $a=10.9478(4) \AA, b=10.9478(4) \AA, c=46.0277(15) \AA, V=5516.6(4) \AA^{3}, Z=8$, $D_{\text {calcd }}=1.317 \mathrm{Mg} / \mathrm{m}^{3}, \lambda(\mathrm{Cu} \mathrm{K} \alpha)=1.54178 \AA$. Intensity data were measured on a Bruker D8 Venture diffractometer up to $\theta_{\max }$ of $75.0^{\circ}$. All 24,967 reflections were collected. The structure was solved by direct methods and refined by a full-matrix least-squares procedure $[27,28]$. The refined structural model converged to a final R1 $=0.0578 ; \mathrm{wR} 2=0.1667$ for 5687 observed reflections $(I>2 \sigma(I))$ and 348 variable parameters. The absolute configuration was determined by the Flack parameter $x=0.095(8)[29,30]$. Crystallographic data for the structure of brianolide (8) were deposited with the Cambridge Crystallographic Data Center (CCDC) under supplementary publication number CCDC 1966097 [31].

\subsection{Molecular Mechanics Calculations}

The MM2 force field [19] in CHEM3D PRO software from CambridgeSoft Corporation (version 15.0, Cambridge, MA, USA) was used to calculate the molecular models.

\subsection{In Vitro Inflammatory Assay}

The inflammatory assay was employed to evaluate the activities of briaranes 1-7 related to the release of iNOS and COX-2 from macrophage cells, as reported in the literature [32].

\section{Conclusions}

Eight chlorinated briarane diterpenoids, including four new briaranes-briarenols W-Z (1-4) — as well as four known analogues—solenolide A (5), briarenolide M (6), briaexcavatolide F (7), and brianolide (8) - were identified from a cultured octocoral B. stechei, originally flourishing in Taiwanese waters where the Kuroshio current and South China Sea surface current converge to provide high biodiversity. The structures of new briaranes 1-4 were elucidated on the basis of spectroscopic analysis and the absolute configuration of 8 (brianolide) was determined by a single-crystal x-ray diffraction analysis. As briaranes 1-7 were isolated along with brianolide (8) from the same target organism, B. stechei, it is reasonable on biogenetic grounds to assume that 1-7 have the same absolute configuration as that of 8, while the protons $\mathrm{H}-10$ and Me- 15 at C- 1 in briaranes 1-8 are $\alpha$ - and $\beta$-oriented, respectively, and these compounds have $1 S, 10 S$ - configurations in the ring junction. Briaranes $\mathbf{2}$ (briarenol $\mathrm{X}$ ) and $\mathbf{5}$ (solenolide A) displayed enhancing effects on the production of iNOS and COX-2 at a concentration of $10 \mu \mathrm{M}$.

Supplementary Materials: The following are available online at https://www.mdpi.com/1660-339 7/19/2/77/s1, ESIMS, HRESIMS, IR, 1D $\left({ }^{1} \mathrm{H}\right.$ and $\left.{ }^{13} \mathrm{C}\right)$ and 2D (HSQC, HMBC, COSY, and NOESY) NMR spectra of briarenols W-Z (1-4).

Author Contributions: Conceptualization, Z.-H.W. and P.-J.S.; investigation, Y.-Y.C., Y.-L.Z., G.-H.L., L.K.T., M.M.Z., H.-P.H., J.-J.C., and C.-Y.K.; writing - original draft preparation, Y.-Y.C., Z.-H.W., and P.-J.S.; writing-review and editing, Y.-Y.C., Z.-H.W., and P.-J.S. All authors have read and agreed to the published version of the manuscript.

Funding: The research was founded by the Ministry of Science and Technology of Taiwan (MOST 107-2320-B-291-001-MY3, 108-2638-B-400-001-MY2, and 109-2320-B-291-001-MY3).

Institutional Review Board Statement: Not applicable.

Data Availability Statement: Any data not included in the manuscript or supplementary materials that supports the work presented in this manuscript is available upon reasonable request to the corresponding author (P.-J.S.).

Acknowledgments: This work was mainly supported by grants from the National Museum of Marine Biology and Aquarium; the Ministry of Science and Technology, Taiwan, awarded to H.-P.H and P.-J.S.; the Center of Applied Nanomedicine, National Cheng Kung University; and the Featured Areas Research Center Program within the framework of the Higher Education Sprout Project of the Ministry of Education (MOE) in Taiwan, awarded to H.-P.H. All funding is gratefully acknowledged.

Conflicts of Interest: The authors declare no conflict of interest. 


\section{References}

1. Burks, J.E.; van der Helm, D.; Chang, C.Y.; Ciereszko, L.S. The crystal and molecular structure of briarein A, a diterpenoid from the gorgonian Briareum asbestinum. Acta Cryst. 1977, B33, 704-709. [CrossRef]

2. Wahlberg, I.; Eklund, A.-M. Cyclized cembranoids of natural occurrence. Fortschr. Chem. Org. Naturst. 1992, 60, 1-141.

3. Chen, Y.-H.; Chin, H.-K.; Peng, B.-R.; Chen, Y.-Y.; Hu, C.-C.; Zheng, L.-G.; Huynh, T.-H.; Su, T.-P.; Zhang, Y.-L.; Wen, Z.-H.; et al. Survey of briarane-type diterpenoids-Part VII. Heterocycles 2020, 100, 857-870.

4. Sung, P.-J.; Hu, W.-P.; Fang, L.-S.; Fan, T.-Y.; Wang, J.-J. Briarenol A, a new diterpenoid from a gorgonian Briareum sp. (Briareidae). Nat. Prod. Res. 2005, 19, 689-694. [CrossRef] [PubMed]

5. $\quad$ Li, M.-J.; Su, Y.-D.; Liao, Z.-J.; Wen, Z.-H.; Su, J.-H.; Wu, Y.-C.; Sung, P.-J. Briarenol B, a new polyoxygenated briarane from the octocoral Briareum excavatum. Nat. Prod. Commun. 2017, 12, 221-224. [CrossRef] [PubMed]

6. Chen, N.-F.; Su, Y.-D.; Hwnag, T.-L.; Liao, Z.-J.; Tsui, K.-H.; Wen, Z.-H.; Wu, Y.-C.; Sung, P.-J. Briarenols C-E, new polyoxygenated briaranes from the octocoral Briareum excavatum. Molecules 2017, 22, 475. [CrossRef] [PubMed]

7. Huynh, T.-H.; Lee, G.-H.; Fang, L.-S.; Sheu, J.-H.; Sung, P.-J. Briarenols F-H: New polyoxygenated briarane diterpenoids produced by the octocoral Briareum excavatum. Tetrahedron Lett. 2020, 61, 151826. [CrossRef]

8. Huynh, T.-H.; Fang, L.-S.; Chen, Y.-H.; Peng, B.-R.; Chen, Y.-Y.; Zheng, L.-G.; Wu, Y.-J.; Wen, Z.-H.; Chen, J.-J.; Lin, T.-C.; et al. new anti-inflammatory 8,17-epoxybriaranes from the octocoral Briareum excavatum (Briareidae). Molecules 2020, 25, 1405. [CrossRef]

9. Huynh, T.-H.; Chang, Y.-M.; Yang, S.-N.; Lee, G.-H.; Wen, Z.-H.; Wu, Y.-J.; Su, T.-R.; Sung, P.-J. Briarenol L, a new chlorinecontaining briaranes from Briareum excavatum (Briareidae). J. Mol. Struct. 2021, 1223, 128970. [CrossRef]

10. Zhang, Y.-L.; Kuo, L.-M.; Chen, L.-Y.; Lee, G.-H.; Peng, B.-R.; Chen, Y.-Y.; Chen, Y.-H.; Hwang, T.-L.; Sheu, J.-H.; Sung, P.-J. Identification and characterization of chlorine-containing briaranes from a cultured octocoral Briareum excavatum (Briareidae). Heterocycles 2020, 100, 1633-1644.

11. Chi, W.-C.; Kuo, L.-M.; Yang, S.-N.; Lee, Y.-T.; Wen, Z.-H.; Tsui, K.-H.; Hwang, T.-L.; Zhang, Y.-L.; Sung, P.-J. Briarenols O and P: Novel briaranes from a cultured octocoral Briareum excavatum (Briareidae). Phytochem. Lett. 2021, 41, 134-138. [CrossRef]

12. Zhang, Y.-L.; Chiang, C.-C.; Lee, Y.-T.; Wen, Z.-H.; Wu, Y.-C.; Wu, Y.-J.; Hwang, T.-L.; Wu, T.-Y.; Chang, C.-Y.; Sung, P.-J. Briarenols Q-T: Briaranes from a cultured octocoral Briareum stechei (Kükenthal, 1908). Mar. Drugs 2020, 18, 383. [CrossRef] [PubMed]

13. Leal, M.C.; Calado, R.; Sheridan, C.; Alimonti, A.; Osinga, R. Coral aquaculture to support drug discovery. Trends Biotechnol. 2013, 31, 555-561. [CrossRef] [PubMed]

14. Samimi-Namin, K.; van Ofwegen, L.P. Overview of the genus Briareum (Cnidaria, Octocorallia, Briareidae) in the Indo-Pacific, with the description of a new species. Zookeys 2016, 557, 1-44. [CrossRef]

15. Groweiss, A.; Look, S.A.; Fenical, W. Solenolides, new antiinflammatory and antiviral diterpenoids from a marine octocoral of the genus Solenopodium. J. Org. Chem. 1988, 53, 2401-2406. [CrossRef]

16. Su, Y.-D.; Wen, Z.-H.; Wu, Y.-C.; Fang, L.-S.; Chen, Y.-H.; Chang, Y.-C.; Sheu, J.-H.; Sung, P.-J. Briarenolides M-T, new briarane diterpenoids from a Formosan octocoral Briareum sp. Tetrahedron 2016, 72, 944-951. [CrossRef]

17. Sheu, J.-H.; Sung, P.-J.; Su, J.-H.; Liu, H.-Y.; Duh, C.-Y.; Chiang, M.Y. Briaexcavatolides A-J, new diterpenes from the gorgonian Briareum excavatum. Tetrahedron 1999, 55, 14555-14564. [CrossRef]

18. Kobayashi, J.; Cheng, J.-F.; Nakamura, H.; Ohizumi, Y.; Tomotake, Y.; Matsuzaki, T.; Grace, K.J.S.; Jacobs, R.S.; Kato, Y.; Brinen, L.S.; et al. Structure and stereochemistry of brianolide, a new antiinflammatory diterpenoid from the Okinawan gorgonian Briareum sp. Experientia 1991, 47, 501-502. [CrossRef]

19. Allinger, N.L. Conformational analysis. 130. MM2. A hydrocarbon force field utilizing $V_{1}$ and $V_{2}$ torsional terms. J. Am. Chem. Soc. 1977, 99, 8127-8134. [CrossRef]

20. Buchholz, B.M.; Chanthaphavong, R.S.; Bauer, A.J. Nonhemopoietic cell TLR4 signaling is critical in causing early lipopolysaccharide-induced ileus. J. Immunol. 2009, 183, 6744-6753. [CrossRef]

21. Jean, Y.-H.; Chen, W.-F.; Duh, C.-Y.; Huang, S.-Y.; Hsu, C.-H.; Lin, C.-S.; Sung, C.-S.; Chen, I.-M.; Wen, Z.-H. Inducible nitric oxide synthase and cyclooxygenase-2 participate in anti-inflammatory and analgesic effects of the natural marine compound lemnalol from Formosan soft coral Lemnalia cervicorni. Eur. J. Pharmacol. 2008, 578, 323-331. [CrossRef] [PubMed]

22. Tai, C.-J.; Su, J.-H.; Huang, M.-S.; Wen, Z.-H.; Dai, C.-F.; Sheu, J.-H. Bioactive eunicellin-based diterpenoids from the soft coral Cladiella krempfi. Mar. Drugs 2011, 9, 2036-2045. [CrossRef] [PubMed]

23. Su, J.-H.; Wen, Z.-H. Bioactive cembrane-based diterpenoids from the soft coral Sinularia triangular. Mar. Drugs 2011, 9, 944-951. [CrossRef] [PubMed]

24. Seibert, K.; Zhang, Y.; Leahy, K.; Hauser, S.; Masferrer, J.; Perkins, W.; Lee, L.; Isakson, P. Pharmacological and biochemical demonstration of the role of cyclooxygenase 2 in inflammation and pain. Proc. Natl. Acad. Sci. USA 1994, 91, 12013-12017. [CrossRef] [PubMed]

25. Zhao, Z.; Chen, S.R.; Eisenach, J.C.; Busija, D.W.; Pan, H.L. Spinal cyclooxygenase-2 is involved in development of allodynia after nerve injury in rats. Neuroscience 2000, 97, 743-748. [CrossRef]

26. Wei, W.-C.; Sung, P.-J.; Duh, C.-Y.; Chen, B.-W.; Sheu, J.-H.; Yang, N.-S. Anti-inflammatory activities of natural products isolated from soft corals of Taiwan between 2008 and 2012. Mar. Drugs 2013, 11, 4083-4126. [CrossRef]

27. Sheldrick, G.M. SHELXT-Integrated space-group and crystal-structure determination. Acta Crystallogr. 2015, A71, 3-8. [CrossRef]

28. Sheldrick, G.M. Crystal structure refinement with SHELXL. Acta Crystallogr. 2015, C71, 3-8.

29. Flack, H.D. On enantiomorph-polarity estimation. Acta Crystallogr. 1983, A39, 876-881. [CrossRef] 
30. Flack, H.D.; Bernardinelli, G. Absolute structure and absolute configuration. Acta Crystallogr. 1999, A55, 908-915. [CrossRef]

31. CCDC Homepage. Available online: http://www.ccdc.cam.ac.uk/conts/retrieving.html (accessed on 30 January 2021).

32. Chen, C.-H.; Chen, N.-F.; Feng, C.-W.; Cheng, S.-Y.; Hung, H.-C.; Tsui, K.-H.; Hsu, C.-H.; Sung, P.-J.; Chen, W.-F.; Wen, Z.-H. A coral-derived compound improves functional recovery after spinal cord injury through its antiapoptotic and anti-inflammatory effects. Mar. Drugs 2016, 14, 160. [CrossRef] [PubMed] 